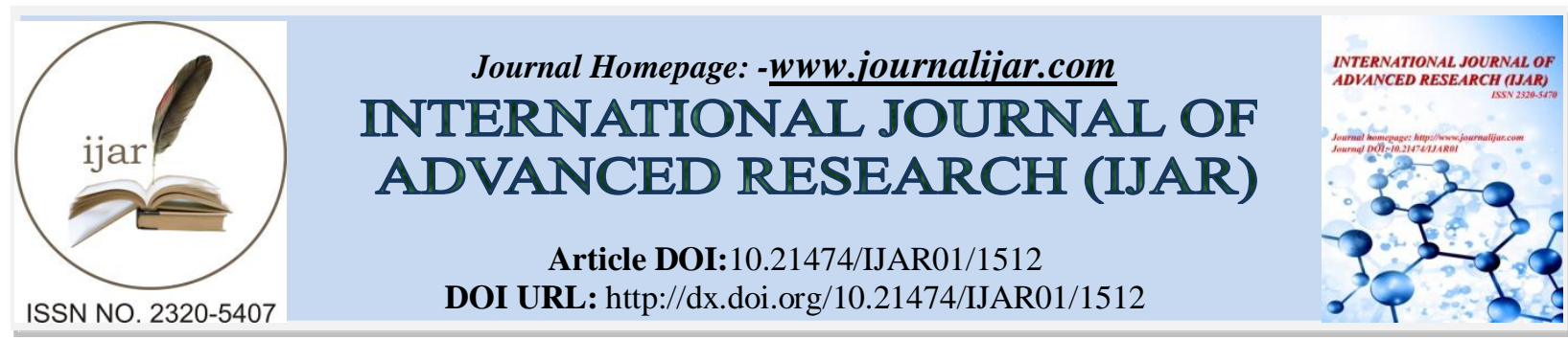

RESEARCH ARTICLE

\title{
EFFECT OF CURCUMIN PRETREATMENT ON CIPROFLOXACIN BIOAVAILBILITY IN RATS.
}

\author{
Dr. K. Kasturi Devi1, Dr. B. Srinu2 and Dr. G. Srinivasa Rao1 \\ 1. Department of Veterinary Pharmacology \& Toxicology,C. V.Sc, Gannavaram. \\ 2. Department of Veterinary public health\&Epidemiology,C.V.Sc,Korutla.
}

\section{Manuscript Info}

Manuscript History

Received: 15 August 2016

Final Accepted: 13 June 2016

Published: September 2016

Key words:-

ciprofloxacin, curcumin,

pharmacokinetics, microbiological assay

\section{Abstract}

Aim:- The experiment was carried out to study the influence of curcumin pre-treatment on pharmacokinetic disposition of ciprofloxacin following single oral administration in adult male wistar rats.

Method:-Twelve rats were divided into two groups of six each .Animals in group-I were administered ciprofloxacin $(10 \mathrm{mg} / \mathrm{kg}$ body weight p.o), while animals in group-II received similar dose of ciprofloxacin after pre-treatment with curcumin $(400 \mathrm{mg} / \mathrm{kg}$ body weight p.o). Rats were anaesthetized after ciprofloxacin administration by xylazine (10-20 mg. $\left.\mathrm{kg}^{-1} \mathrm{IP}\right)$ and ketamine (44-100 mg.kg ${ }^{-1}$ IP). Blood samples $(200 \mu \mathrm{l})$ were collected into heparinised centrifuge tubes by tail vein clipping or jugular vein puncture as per convenience, prior to and at $0.33,0.67,1,1.5,2,4,6,8$ and $12 \mathrm{~h}$ time intervals. Plasma concentrations of ciprofloxacin were determined by microbiological assay.

Pharmacokinetic Analysis:-Plasma concentration versus time data of ciprofloxacin obtained in control and in pretreated group was utilized for calculating various pharmacokinetic parameters $\left(\beta, \mathrm{t}_{1 / 2 \beta}, \mathrm{AUC}_{0-\infty}\right.$, $\mathrm{AUMC}_{0-\infty}, \mathrm{V}_{\mathrm{d}}, \mathrm{Cl}_{\mathrm{B}}$, and MRT) by non compartmental methods (Gibaldi and Perrier, 1982) and computer software (PK Solver Version 2.0, 2010 by Zhang Yang).

Statistical analysis:- All data were expressed as Mean \pm SEM. Differences in pharmacokinetic data between groups were analysed for statistical significance using unpaired student's' $t$ ' test with Welch's correction using 'Instat' software

Results:- Peak plasma drug concentration $\left(\mathrm{C}_{\max }\right), \mathrm{AUC}_{0-\infty}$, elimination half life $t^{1} 122_{\beta}$, Mean residence time (MRT) were significantly $(p<0.05)$ longer in curcumin pretreated group. There is significant decrease in Steady state volume of distribution $\mathrm{V}_{\mathrm{dss}}$ andtotal body clearance $\mathrm{Cl}_{\mathrm{B}}$ in curcumin pretreated rats than in ciprofloxacin alone group.

Conclusion:- The present study concluded that pretreatment with curcumin enhanced oral bioavailability of ciprofloxacin in rats.

Copy Right, IJAR, 2016,. All rights reserved. 


\section{Introduction:-}

Ciprofloxacin is a broad spectrum fluoroquinolone antimicrobial agent widely used against gram positive and gram negative bacteria ${ }^{1}$. It is reported that active efflux transporters are involved in secretion of ciprofloxacin and other fluoroquinolones into the intestinal lumen ${ }^{2}$, a clinically important route of elimination. Murine bcrp1 mediates active efflux of ciprofloxacin across apical membrane of bcrp1-overexpressing MDCKII cell monolayers ${ }^{3}$. Multi drug resistance protein-MRP4 is involved in ciprofloxacin transport in both ciprofloxacin-resistant and wild-type cells, suggesting that MRP4 is most likely transporter of ciprofloxacin in murine macrophages ${ }^{4}$. Further, co-administration of MRP4 inhibitor dipyridamole has increased in systemic exposure of ciprofloxacin in rats ${ }^{5}$.

Curcumin is the principal curcuminoid of the popular Indian spice turmeric, which is a member of the ginger family (Zingiberaceae). The other two curcuminoids are desmethoxycurcumin and bis-desmethoxycurcumin ${ }^{6}$. Curcumin has wide range of pharmacological properties such as antioxidant, anti inflammatory, anti viral, antifungal, hepatoprotective action ${ }^{6}$. In addition to these beneficiary effects curcumin and its metabolite tetrahydro curcumin were found to inhibit ATP-binding cassette (ABC) transporters Pgp, MRP1, and BCRP ${ }^{7}$.

ATP-binding cassette transporters are membrane-bound proteins expressed virtually in all living organisms including prokaryotes ${ }^{8}$.These proteins are expressed predominantly in liver, epithelia of intestine, blood-brain barrier, kidneys, mammary gland, placenta and they largely determine drug absorption, distribution, metabolism and excretion and affect the overall pharmacokinetic properties of drugs ${ }^{9}$. Most of the effectiveness of the drugs currently used is limited by the decreased bioavailability mediated by ATP binding cassette (ABC) group of drug transporters including p-glycoprotein (P-gp, ABCB1), multi drug resistance associated proteins (MRPs) -(MRP1, $\mathrm{ABCC} 1)(\mathrm{MRP} 2, \mathrm{ABCC} 2)(\mathrm{MRP} 4, \mathrm{ABCC} 4)$ and breast cancer resistance protein (BCRP,ABCG2).

With this background, considering ciprofloxacin is a substrate of efflux transporters multi drug resistance protein MRP4 and BCRP, curcumin has inhibitory effects on multiple ABC drug transporters, the present study was undertaken to evaluate the influence of curcumin pretreatment over on the bioavailability of ciprofloxacin.

\section{Materials and methods:- \\ Materials:-}

Cifran $^{\circledR}$ (ciprofloxacin $250 \mathrm{mg}$ ) tablets were procured from Ranbaxy, India for oral administration. For microbiological assay technical grade ciprofloxacin was generous gift from PVS Laboratories (Vijayawada, India). Curcumin of analytical grade compounds and Heparin (20,000 IU/vial) were purchased from Loba Chemie, India. Xylazine was obtained from Indian Immunologicals Ltd., Ketamine hydrochloride was procured from Themis Medicare Ltd, India. Escherichia coli ATCC 25922 obtained from Post Graduate Institute of Medical Education, Chandigarh, India was used in bioassay. Mueller-Hinton Broth was purchased from HiMedia, India.

Adult male rats of Wistar albino strain were procured from Mahaveer Enterprises ～(Regd No: 146/1999/CPCSEA), Hyderabad. They were maintained under standard management and husbandry conditions with free access to feed and water. The experiments were approved by Institutional Animal Ethics Committee (IAEC), N.T.R College of Veterinary Science, Gannavaram

\section{Methods:- \\ Preparation of standard drug solutions:-}

Ciprofloxacin $\left(1 \mathrm{mg} . \mathrm{mL}^{-1}\right)$ solution was used for preparing working standards $(0.06,0.12,0.25,0.5,1,2,4$ and 8.0 $\left.\mu \mathrm{g} . \mathrm{mL}^{-1}\right)$ by serial dilution with phosphate buffer $(\mathrm{pH} \mathrm{7.4)}$ and drug free rat plasma. These standards of known concentrations were assayed by agar well diffusion method by using Escherichia coli (ATCC 25922) as described by ${ }^{10}$. The diameter of zone $(\mathrm{mm})$ of inhibition was plotted against concentrations of standards to obtain standard curves for ciprofloxacin. The standard curves were linear in the range of $0.12-1.0 \mu \mathrm{g} / \mathrm{ml}$ with $\mathrm{R}^{2}=0.987$, Figure 1 . The minimal limit of detection of ciprofloxacin was found to be $0.06 \mu \mathrm{g} / \mathrm{ml}$. 


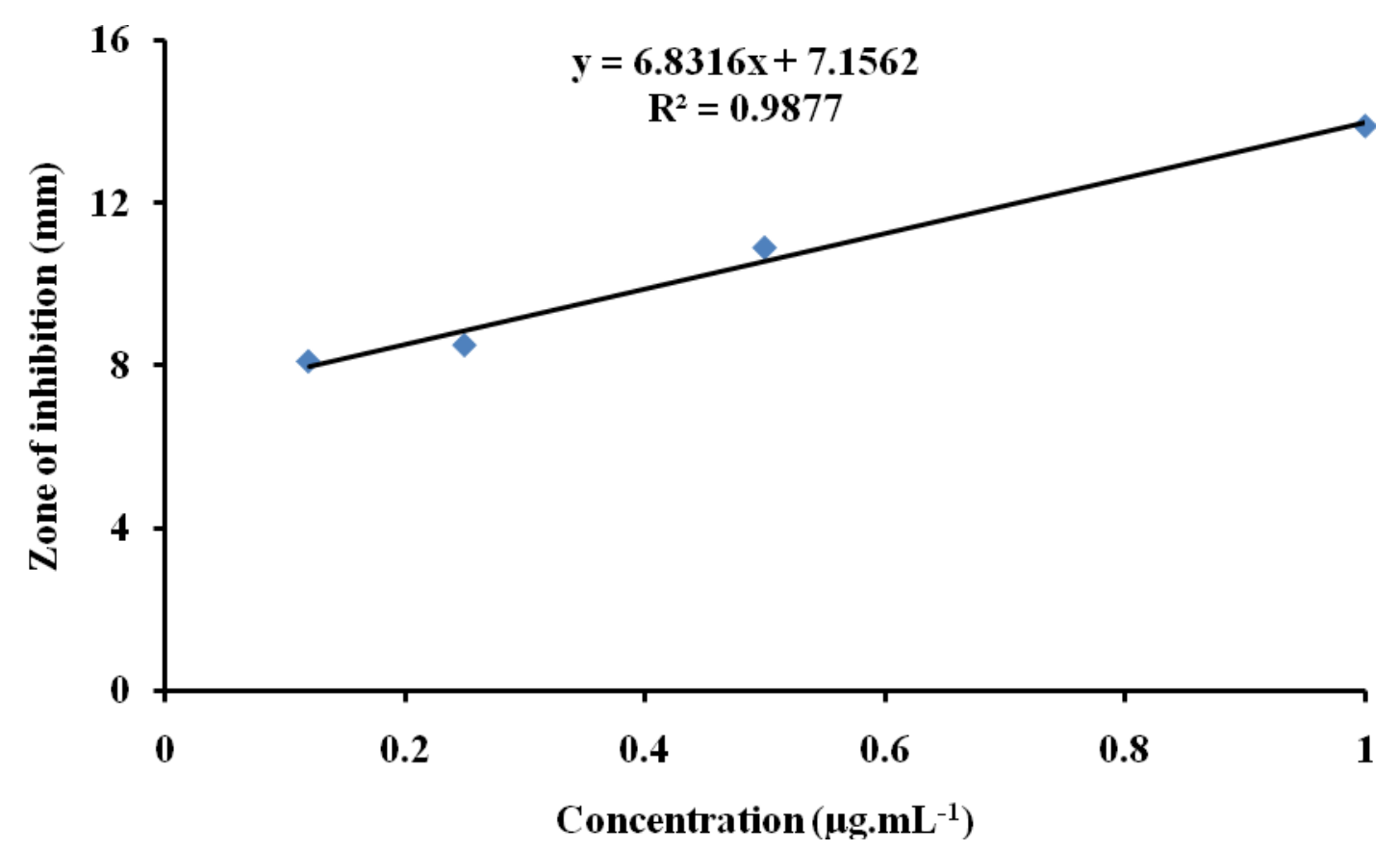

Figure 1:- Standard calibration curve of ciprofloxacin in rat plasma.

The microbiological assay employed in the present study to measure the concentrations of ciprofloxacin in plasma, was also used previously by many authors to measure the concentrations of fluoroquinolones including ciprofloxacin in the plasma/serum of animals $\mathrm{s}^{11,12,13,14}$. It was found that bioassay method correlates well with HPLC studies $^{15,16}$.

\section{Experimental design:-}

Rats were off feed 12 hours prior to the experimentation, with ad libitum access to water. Body weight of the rats was taken just before the experiment. Ciprofloxacin was administered as single oral dose $\left(10 \mathrm{mg} \cdot \mathrm{kg}^{-1}\right.$, per os $)$ in both groups whereas in group II rats, ciprofloxacin was given after 30 min of pretreatment with curcumin (400 $\mathrm{mg} \cdot \mathrm{kg}^{-1}$, per os). Rats were anaesthetized after administration of ciprofloxacin by xylazine $\left(10-20 \mathrm{mg} \cdot \mathrm{kg}^{-1}\right)$ and ketamine (44-100 mg. $\left.\mathrm{kg}^{-1}\right)$ intramuscularly. Blood samples $(0.2 \mathrm{~mL})$ were drawn into heparinized tubes from jugular vein and by tail clipping prior to and at $0.33,0.67,1,1.5,2,4,6,8$ and $12 \mathrm{~h}$ time intervals after ciprofloxaicin administration. They were centrifuged at $3000 \mathrm{rpm}$ for $10 \mathrm{~min}$ and plasma was harvested and kept at $-20^{\circ} \mathrm{C}$ till analysed for ciprofloxacin by microbiological assay using agar well diffusion method.

\section{Pharmacokinetic Analysis:-}

Plasma concentration versus time data of ciprofloxacin obtained in control and in pretreated group with curcumin in the present study was utilized for calculating various pharmacokinetic parameters $\left(\beta, t_{1 / 2 \beta}, \mathrm{AUC}_{0-\infty}, \mathrm{AUMC}_{0-\infty}, \mathrm{V}_{\mathrm{d}}\right.$, $\mathrm{Cl}_{\mathrm{B}}$, and MRT) in rats by non compartmental methods and computer software (PK Solver Version 2.0, 2010 by Zhang Yang). Peak plasma ciprofloxacin concentration $\left(\mathrm{C}_{\max }\right)$ and time to reach peak concentration $\left(\mathrm{t}_{\max }\right)$ for were calculated from actual plasma data of each rat. Elimination rate constant $(\beta)$ of ciprofloxacin which was calculated by least square regression analysis method. The area under the time plasma concentration $\left(\mathrm{AUC}_{0-\mathrm{t}}\right)$ of ciprofloxacin was calculated by linear trapezoidal rule, the $\left(\mathrm{AUC}_{\mathrm{t}-\infty}\right)$ was calculated by dividing the last plasma concentration of the drug $\left(\mathrm{C}_{\mathrm{t} \text { last }}\right)$ by elimination rate constant $(\beta)$. $\mathrm{AUMC}_{0-\mathrm{t}}$ was also determined linear trapezoidal rule. The elimination half life $\left(t_{1 / 2 \beta}\right)$ was calculated by using the formula $t_{1 / 2 \beta}=0.693 / \beta$.

The mean residence time $(\mathrm{MRT})$ was estimated from $\mathrm{MRT}=\mathrm{AUMC}_{0-\infty} / \mathrm{AUC}_{0--\infty}$

$\left(\mathrm{V}_{\mathrm{d}}\right)$ and $\left(\mathrm{Cl}_{\mathrm{B}}\right)$ were calculated using equations $\mathrm{V}_{\mathrm{d}}=$ Dose $\mathrm{x} \mathrm{AUMC}_{0-\infty} /\left(\mathrm{AUC}_{0--\infty}\right)$ 


\section{Statistical Analysis:-}

$$
\mathrm{Cl}_{\mathrm{B}}=\operatorname{Dose} /\left(\mathrm{AUC}_{0-\infty}\right)
$$

All data were expressed as Mean \pm SEM. Differences in pharmacokinetic data between ciprofloxacin alone and pretreated curcumin groups were analysed for statistical significance using unpaired student's' $t$ ' test with Welch's correction using 'Instat' software. Difference of $(p<0.05)$ and $(p<0.01)$ were considered statistically significant.

\section{Results:-}

The mean plasma concentrations of ciprofloxacin obtained in the present study is shown in (Table 1). It was found that $\mathrm{C}_{\max }$ of ciprofloxacin was significantly $(\mathrm{p}<0.01)$ higher in curcumin pretreated group $\left(1.74 \pm 0.052 \mu \mathrm{g} \cdot \mathrm{mL}^{-1}\right)$ than in control $\left(1.12 \pm 0.18 \mu \mathrm{g} \cdot \mathrm{mL}^{-1}\right)$. The plasma concentration of ciprofloxacin persisted up to $8 \mathrm{~h}$ in curcumin pretreated rats, while it was detected up to $6 \mathrm{~h}$ in the untreated group as shown in fig. 2. The pharmacokinetic parameters estimated by non-compartmental analysis of plasma concentrations of ciprofloxacin with and without curcumin pretreated rats are presented in Table 2.

Prior administration of curcumin modified the kinetic profile of ciprofloxacin as evidenced by the significant $(\mathrm{p}<0.01)$ increase in AUC, AUMC from 2.38 \pm 0.31 to $6.03 \pm 1.01 \mu \mathrm{g} \cdot \mathrm{h} \cdot \mathrm{mL}^{-1}$ and $6.26 \pm 1.24$ to $35.37 \pm 15.10 \mu \mathrm{g} \cdot \mathrm{h}^{2} . \mathrm{mL}^{-}$ ${ }_{1}^{1}$ respectively, whereas $\mathrm{V}_{\mathrm{d}}$ and $\mathrm{Cl}_{\mathrm{B}}$ were significantly decreased from $10.98 \pm 0.78$ to $8.31 \pm 0.82 \mathrm{~L}^{-\mathrm{kg}^{-1}}$ and $4.56 \pm 0.56$

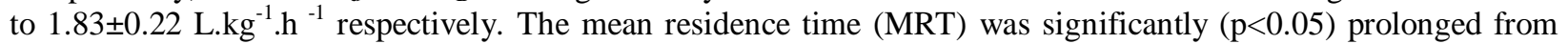
$2.52 \pm 0.2$ to $5.03 \pm 1.06 \mathrm{~h}$. Further treatment with curcumin increased elimination half life significantly $(\mathrm{p}<0.05)$ from $1.85 \pm 0.22$ to $3.49 \pm 0.77 \mathrm{~h}$.

Table 1:-Effect of curcumin pretreatment on concentrations of ciprofloxacin in plasma (Mean \pm SE) after single oral administration of ciprofloxacin at $10 \mathrm{mg} \cdot \mathrm{kg}^{-1}(\mathrm{n}=6)$.

\begin{tabular}{|l|l|l|}
\hline Time (h) & Ciprofloxacin & Curcumin+Ciprofloxacin \\
\hline $\mathbf{0 . 1 6}$ & $0.65 \pm 0.05$ & $0.948 \pm 0.243$ \\
\hline $\mathbf{0 . 3 3}$ & $0.75 \pm 0.04$ & $1.215 \pm 0.272$ \\
\hline $\mathbf{0 . 6 7}$ & $0.80 \pm 0.02$ & $1.365 \pm 0.194^{*}(\mathrm{p}=0.0158)$ \\
\hline $\mathbf{1}$ & $1.03 \pm 0.2$ & $0.942 \pm 0.171 \mathrm{~s}$ \\
\hline $\mathbf{1 . 5}$ & $0.57 \pm 0.08$ & $0.902 \pm 0.155$ \\
\hline $\mathbf{2}$ & $0.33 \pm 0.04$ & $0.67 \pm 0.062^{*}(\mathrm{p}=0.0015)$ \\
\hline $\mathbf{4}$ & $0.17 \pm 0.023$ & $0.542 \pm 0.067^{*}(\mathrm{p}=0.0004)$ \\
\hline $\mathbf{6}$ & $0.13 \pm 0.004$ & $0.383 \pm 0.073$ \\
\hline $\mathbf{8}$ & $\mathrm{ND}^{1}$ & $0.21 \pm 0.054$ \\
\hline
\end{tabular}

Note: ND means Not detected.

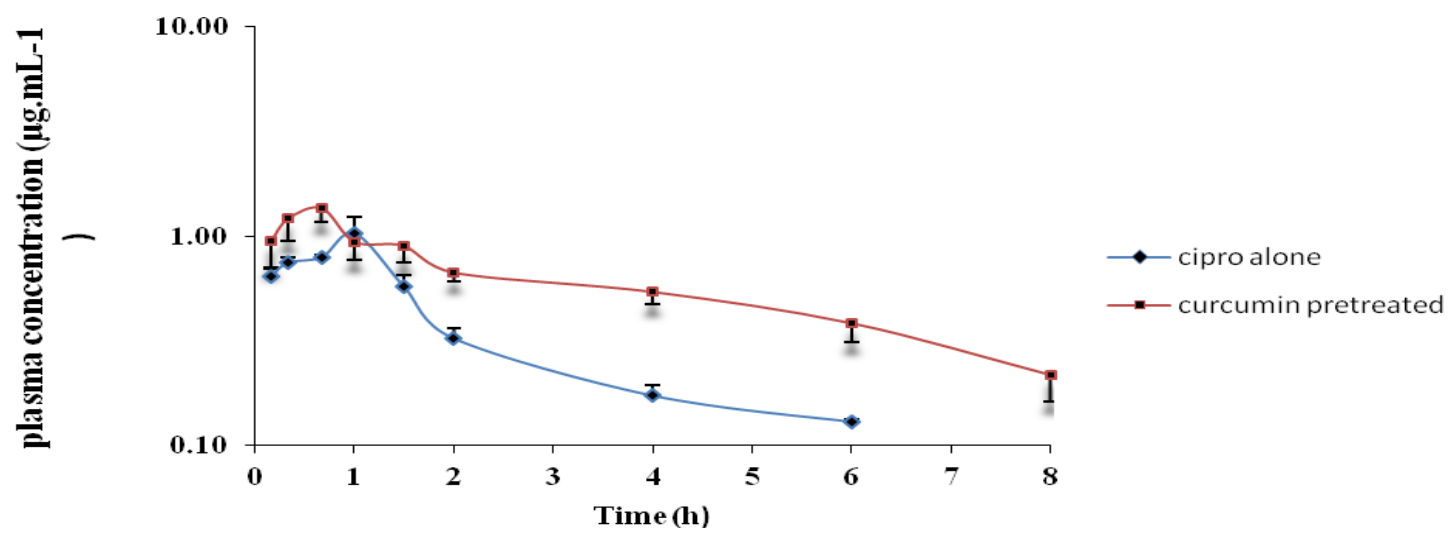

Figure 2:-Semilogarithmic plot of ciprofloxacin concentrations in plasma versus time after single oral bolus administration of ciprofloxacin (10 mg. $\left.\mathrm{kg}^{-1}\right)$ in ciprofloxacin alone (Blue plot) and curcumin pretreated (Red plot) in adult male wistar rats. Each point represents the mean \pm SE of six rats 
Table 2:-Effect of curcumin pretreatment on pharmacokinetic parameters of ciprofloxacin in rats after single oral dose administration of ciprofloxacin $\left(10 \mathrm{mg} \cdot \mathrm{kg}^{-1}\right)(\mathrm{n}=6)$.

\begin{tabular}{|l|l|l|l|}
\hline Parameter & Unit & Ciprofloxacin alone & Curcumin+Ciprofloxacin \\
\hline$\beta$ & $\mathrm{h}^{-1}$ & $0.404 \pm 0.05$ & $0.237 \pm 0.037^{*}$ \\
\hline $\mathrm{t} 1 / 2 \beta$ & $\mathrm{h}$ & $1.85 \pm 0.22$ & $3.49 \pm 0.77^{* *}$ \\
\hline $\mathrm{AUC}_{0-\mathrm{t}}$ & $\mu \mathrm{g} \cdot \mathrm{h} \cdot \mathrm{mL}^{-1}$ & $2.028 \pm 0.28$ & $4.67 \pm 0.39^{* *}$ \\
\hline $\mathrm{AUC}_{0-\infty}$ & $\mu \mathrm{g} \cdot \mathrm{h} \cdot \mathrm{mL}^{-1}$ & $2.38 \pm 0.31$ & $6.03 \pm 1.01^{* *}$ \\
\hline $\mathrm{AUC}_{\mathrm{t}-\infty} / \mathrm{AUC}_{0-\infty}$ & $\%$ & $14.98 \pm 1.72$ & $18.46 \pm 5.54$ \\
\hline $\mathrm{AUMC}_{0-\mathrm{t}}$ & $\mu \mathrm{g} \cdot \mathrm{h}^{2} \cdot \mathrm{mL}^{-1}$ & $3.42 \pm 0.72$ & $13.94 \pm 1.97$ \\
\hline $\mathrm{AUMC} \mathrm{C}_{0-\infty}$ & $\mu \mathrm{g} \cdot \mathrm{h}^{2} \cdot \mathrm{mL}^{-1}$ & $6.26 \pm 1.24$ & $35.37 \pm 15.10^{* *}$ \\
\hline $\mathrm{MRT}$ & $\mathrm{h}$ & $2.52 \pm 0.2$ & $5.03 \pm 1.06^{*}$ \\
\hline $\mathrm{V}_{\mathrm{dss}}$ & $\mathrm{L} \cdot \mathrm{kg}^{-1}$ & $10.98 \pm 0.78$ & $8.31 \pm 0.82^{*}$ \\
\hline $\mathrm{Cl}_{\mathrm{B}}$ & $\mathrm{L} \cdot \mathrm{kg}^{-1} \cdot \mathrm{h}^{-1}$ & $4.56 \pm 0.56$ & $1.83 \pm 0.22^{* *}$ \\
\hline $\mathrm{C}_{\max }$ & $\mu \mathrm{g} \cdot \mathrm{mL}^{-1}$ & $1.12 \pm 0.18$ & $1.74 \pm 0.052^{* *}$ \\
\hline $\mathrm{t}_{\max }$ & $\mathrm{h}$ & $0.67 \pm 0.12$ & $0.6 \pm 0.19$ \\
\hline $\mathrm{V}_{\mathrm{a}}$ & & \\
\hline
\end{tabular}

Values are expressed as Mean \pm SEM.

"Significantly different $(\mathrm{p}<0.05)$ from respective normal values

${ }^{* *}$ Significantly different $(\mathrm{p}<0.01)$ from respective normal values

\section{Discussion:-}

Ciprofloxacin is a fluorinated quinolone carboxylic acid derivative used both in humans and veterinary practice to treat respiratory, gastro-intestinal, urogenital infections. It was reported that intestinal elimination of ciprofloxacin appears to be a leading cause for low oral bioavailability of between $50 \%$ and $80 \%{ }^{17}$.It was reported that active secretion of ciprofloxacin both in human and rodent intestine is attenuated by specific BCRP inhibitor, Ko $143^{3}$ and co-administration of MRP4 inhibitor, dipyridamole has increased systemic exposure of ciprofloxacin in rats ${ }^{5}$. One of the activities of curcumin that has been reported to be of great interest is its ability to inhibit the drug efflux mediated by major ATP-binding cassette $(\mathrm{ABC})$ transporters such as P-gp, ABCG2, MRP1 ${ }^{18}$.

In the present study, the plasma concentration-time profile indicates peak plasma drug concentration $\left(\mathrm{C}_{\max }\right)$ and $\mathrm{AUC}_{0-\infty}$ are significantly $(\mathrm{p}<0.01)$ high in curcumin pretreated group. The elimination half life $\mathrm{t}^{1} / 2_{\beta}$, Mean residence time (MRT) of ciprofloxacin are significantly $(\mathrm{p}<0.05)$ longer in curcumin pretreated group than that of control group. There is a significant decrease in total body clearance $\mathrm{Cl}_{\mathrm{B}}$ in curcumin pretreated rats than in ciprofloxacin alone group, indicating decreased clearance of ciprofloxacin. It might be due to inhibitory effect of curcumin on drug efflux transporters which mediate active intestinal secretion of ciprofloxacin in oral administration. These findings are in accordance with ${ }^{19}$, where curcumin pretreatment increased absorption levels of norfloxacin in rabbits. However the concept of improving oral bioavailability of concentration dependent antibiotics likes ciprofloxacin, by using natural inhibitors like curcumin which are relatively non toxic to host is of beneficial therapeutic approach. For example, Ko143 and GF120918, which are well characterized and potent inhibitors of ABCG2 and ABCB1, have an IC50 value of 19 and $18 \mu \mathrm{M}$ for MCF-7 cells ${ }^{20}$ respectively, while curcuminoids have IC50 values in the range of $25-50 \mu \mathrm{M}$ for the same cells ${ }^{18}$ (Chearwae et al.,., 2006).

\section{Conclusion:-}

This study suggested the prospective use of non-toxic natural products to improve the oral bioavailability of antibiotics. However to confirm the interpretation, curcumin inhibiting ciprofloxacin active intestinal secretion, it is necessary to conduct experiments upon the role of curcumin over the regulation of efflux transporters mRNA expression along the intestine. 


\section{References:-}

1. Omari Derar M., Dalia Johary, Isam I. Salem, Naji Najib and Assayed A.Sallam, Bioequivalence of Two Oral Extended Release Formulations of Ciprofloxacin Tablets in Healthy Male Volunteers under Fed and Fasting Conditions. Journal of bioequivalence and bioavailability 2011; Volume 3(2): 038-042.

2. Lowes, S. \& N. L. Simmons,. Multiple pathways for fluoroquinolone secretion by human intestinal epithelial (Caco-2) cells. British Journal of Pharmacology, 2002; 135, 1263-1275.

3. Haslam I. S., J. A. Wright, D. A. O'Reilly, D. J. Sherlock, T. Coleman, and N. L. Simmons,. Intestinal Ciprofloxacin Efflux: The Role of Breast Cancer Resistance Protein (ABCG2). Drug metabolism and disposition. 2011; Vol. 39, No. 12

4. Marquez Be'atrice, Nancy E. Caceres, Marie-Paule Mingeot-Leclercq, Paul M. Tulkens, and Franc, oise Van Bambeke. Identification of the Efflux Transporter of the Fluoroquinolone Antibiotic Ciprofloxacin in Murine Macrophages: Studies with Ciprofloxacin-Resistant Cells. Antimicrobial agents and chemotherapy. 2009 ; Vol. 53, No. 6

5. Prasad VG, Achanta S, Tammineni YR, Alla GR, Thirtham MR, Rao GS,. Effect of Multi Drug Resistance Protein 4 (MRP4) Inhibition on the Pharmacokinetics and Pharmacodynamics of Ciprofloxacin in Normal and Rats with LPS-Induced Inflammation. Eur J Drug Metabolism and Pharmacokinetics. 2015; Oct 13

6. Akram M., shahab-uddin, afzal ahmed, khan usmanghani. Curcuma longa and curcumin: a review article. Rom. J. Biol. - plant biol., 2007; volume 55, no. 2, p. 65-70.

7. Wu Chung-Pu, Shinobu Ohnuma, Suresh V. Ambudkar. Discovering Natural Product Modulators to Overcome Multidrug Resistance in Cancer Chemotherapy. Curr Pharm Biotechnol. 2011; 12(4): 609-620.

8. Jones Peter M. and Anthony M. George. Mechanism of ABC transporters: A molecular dynamics simulation of a well characterized nucleotide binding -subunit. PNAS. 2002 ; vol .99 Page no.20

9. Choi $\mathrm{YH}, \mathrm{Yu}$ AM. Young Hee Choi and Ai-Ming $\mathrm{Yu}, \mathrm{ABC}$ transporters in multidrug resistance and pharmacokinetics, and strategies for drug development. Curr Pharm Des. 2014; .20(5):793-807

10. Arret, B., Johnson, D.P. and Kirshbaum, A. Outline of details for microbiological assaysof antibiotics: second revision. Journal of pharmaceutical sciences 1971; 60, 1689-1694

11. Haritova, A.M., Rusenova, N.M., Parvanov, P.R., Lashev, L.D. and Gremmels, J.F. Integration of pharmacokinetic and pharmacodynamic indices of marbofloxacinin turkeys. Antimicrobial agents and chemotherapy 2006; 3779-3785.

12. Akhtar, H; Muhammed, F; Muhammed, S.A. Effect of antipyrine on disposition kinetics of ciprofloxacin in dogs. Pharmacology online 2007; 1: 581-587.

13. Raina R., Prawez S., Dimitrovaz D.J., Pankaj N.K. Verma P.K. Disposotion kinetics and urinary excretion of ciprofloxacin in goats. Journal of Veterinary Science 2008;. 9(3),241-245

14. Muhammed, K. K. and Muhammed, F. Comparative bioequivalence and pharmacokinetics of ciprofloxacin in healthy male subjects. Pakistan journal of pharmaceutical science 2009; volume22:1: page number 1-7.

15. Abdelaziz Ahmed A., Tarek E. Elbanna, Noha M. Gamaleldeen. Validated microbiological and hplc methods for the determination of moxifloxacin in pharmaceutical preparations and human plasma. Brazilian Journal of Microbiology 2012; 1291-1301

16. Manfio Maria Luisa, Danielle Araújo Agarrayua, Jaison Carlosso Machado, Cleber Alberto Schmidt. A fully validated microbiological assay to evaluate the potency of ceftriaxone sodium. Brazilian Journal of Pharmaceutical Sciences 2013; vol. 49, n. 4, oct./dec.

17. Sorgel F., Naber K.G., Jaehde U., Reiter, A., Seelmann, R. and Sigl G. Gastro intestinalsecretion of ciprofloxacin. Evaluation of the charcoal model for investigation in healthy volunteers. American Journal of Medicine. 1989; 87(suppl 5A):62S-65S

18. Chearwae W., S. Shukla, P. Limtrakul, and S. V. Ambudkar. Modulation of the function of the multidrug resistance-linked ATP-binding cassette transporter ABCG2 by the cancer chemopreventive agent curcumin. Mol. Cancer Ther. 2006; 5:1995-2006.

19. Pavithra B. H., Prakash N., Jayakumar K.Modification of pharmacokinetics of norfloxacin following oral administration of curcumin in rabbits, J. Vet. Sci. 2009; 10(4), 293-297

20. Allen John D. and Alfred H. Schinkel. Multidrug Resistance and Pharmacological Protection Mediated by the Breast Cancer Resistance Protein (BCRP/ABCG2).Molecular Cancer Therapeutics. 2002; Vol. 1, 427-434, 